\title{
PENGARUH MODEL RECIPROCAL TEACHING TERHADAP KETERAMPILAN MENULIS BAHASA INDONESIA
}

\author{
Yulia Indah Sari \\ Program Studii Pendidikan Guru Sekolah Dasar Universitas Pendidikan Ganesha \\ govipp99@gmail.com \\ I Ketut Adnyana Putra \\ Program Studii Pendidikan Guru Sekolah Dasar Universitas Pendidikan Ganesha \\ ketut.adnyana.putra@undiksha@ac.id \\ Ni Wyn. Suniasih \\ Program Studii Pendidikan Guru Sekolah Dasar, Universitas Pendidikan Ganesha \\ wayansuniasih@yahoo.co.id
}

\begin{abstract}
Abstrak
Penelitian ini bertujuan untuk mengetahui pengaruh model Reciprocal Teaching terhadap keterampilan menulis bahasa Indonesia siswa kelas V SD Gugus I Kecamatan Gianyar tahun ajaran 2017/2018. Penelitian ini merupakan penelitian eksperimen semu dengan rancangan penelitian yang digunakan adalah Rancangan Kelompok Non-ekuivalen. Populasi dalam penelitian ini adalah seluruh siswa kelas V SD Gugus I Kecamatan Gianyar yang berjumlah 480 siswa. Sampel penelitian ini sebanyak 82 siswa terdiri dari 45 siswa kelompok eksperimen dan 37 siswa kelompok kontrol yang ditentukan dengan menggunakan teknik sampel kelompok. Metode pengumpulan data dalam penelitian ini adalah metode tes dalam bentuk tes keterampilan menulis. Data yang diperoleh menunjukkan bahwa rata-rata gain skor ternormalisasi keterampilan menulis bahasa Indonesia siswa pada kelompok eskperimen lebih dari rata-rata gain skor ternormalisasi

pada kelompok kontrol, yaitu $\bar{X}_{=0,433>} \bar{X}_{=0,284}$. Berdasarkan hasil analisis data dengan menggunakan uji-t dengan rumus polled varians diperoleh harga $\mathrm{t}_{\text {hitung }}=4,139>\mathrm{t}_{\text {tabel }}=2,000$ pada taraf signifikansi $5 \%$ dan dk $=80$. Hal ini menunjukkan bahwa terdapat pengaruh model Reciprocal Teaching terhadap keterampilan menulis bahasa Indonesia siswa kelas V SD Gugus I Kecamatan Gianyar tahun ajaran 2017/2018. Berdasarkan hasil penelitian ini disarankan untuk penelitian selanjutnya mengkaji lebih luas mengenai keterampilan menulis bahasa Indonesia siswa dan memperdalam teori mengenai model Reciprocal Teaching.
\end{abstract}

Kata kunci: model Reciprocal Teaching, keterampilan menulis.

\begin{abstract}
This research was aimed to know the effect of Reciprocal Teaching model for the writing skills Indonesian language students grade fifth primary school at Gugus I Gianyar Sub District in academic year 2017/2018. This research is a quasi-experimental research with the research design used is non-equivalent group design. The populations of the fifth grade at Gugus I Gianyar Sub District which amounts to 480 students. The sample of the research is 82 students consist of 45 experimental group students and 37 control group students who determined with group sample technique. Data collection method in this research is test method. The data obtained shows that the average normalized gain score of writing skills in experimental group greater than the average

normalized gain score in control group $\left(\overline{\bar{X}_{1}}=0,433>\overline{X_{2}}=0,284\right)$. The result of the research based on data analyze by $\mathrm{t}$-test with polled variants formula, there was obtained $\mathrm{t}_{\mathrm{c}}=4.333>\mathrm{t}_{\text {table }}=2,000$ at significant level $5 \%$ and $\mathrm{dk}$ $=80$. Accordance to the result it prove that Reciprocal Teaching model have an effect of the writing skills Indonesian language students grade fifth primary school at Gugus I Gianyar Sub District in academic years 2017/2018. Accordance to the result of this study, for turther research it is suggested to extensively reviewing students writing skills Indonesia language and the theories on Reciprocal Teaching.
\end{abstract}

Keywords: Reciprocal Teaching models, writing skills. 


\section{Pendahuluan}

Perubahan yang terjadi secara global dalam bidang ilmu pengetahuan dan teknologi, serta seni dan budaya menuntut adanya perkembangan dan perubahan dalam kehidupan bernegara. Adanya pengaruh dari perubahan global ini menjadikan setiap negara berupaya untuk melakukan perubahan dan perbaikan, termasuk dalam dunia pendidikan. Hal ini berkaitan dengan salah satu indikator sebuah negara dikatakan sebagai negara yang maju dengan melihat kualitas pendidikannya. Semakin baik tingkat pendidikan suatu negara, maka semakin baik pula kualitas sumber daya manusia yang dihasilkan.

Kemajuan suatu negara dengan kualitas pendidikan yang diberikan merupakan suatu kesatuan utuh yang tak terpisahkan, oleh karenanya perbaikan-perbaikan terhadap mutu pendidikan yang ada selalu dilakukan sebagai upaya menciptakan sumber daya manusia yang unggul dan mencapai keberhasilan pembangunan sebuah negara. Di Indonesia pendidikan dilandasi oleh Pancasila sebagai falsafah bangsa, dan Undang Undang Dasar 1945 yang dengan jelas merumuskan tujuan pendidikan nasional sebagai upaya untuk mencerdaskan kehidupan bangsa. Lebih lanjut dalam Pasal 3 UU No 20 Sisdiknas Tahun 2003 disebutkan tentang fungsi dan tujuan pendidikan nasional untuk mengembangkan kemampuan dan membentuk watak serta peradaban bangsa dalam rangka mencerdaskan kehidupan bangsa, bertujuan untuk berkembangnya potensi peserta didik agar menjadi manusia yang beriman dan bertaqwa kepada Tuhan Yang Maha Esa, berakhlak mulia, sehat, berilmu, cakap, kreatif, mandiri, dan menjadi warga negara yang demokratis serta bertanggung jawab.

Sejalan dengan hal tersebut, pemerintah Indonesia berupaya memperbaiki mutu pendidikan bangsa untuk mewujudkan masyarakat Indonesia yang mampu bersaing dan sebagai bentuk penyesuaian diri terhadap perubahan zaman dengan beberapa kali melakukan perubahan dan perbaikan pada kurikulum yang berlaku. Adapun kurikulum yang saat ini diberlakukan di Indonesia yaitu Kurikulum 2013. Kurikulum 2013 merupakan kurikulum pengganti dan penyempurna kurikulum sebelumnya yaitu kurikulum 2006 atau kurikulum KTSP (Darmayasa, 2016).

Kurikulum 2013 dalam penerapannya menjadikan peran guru bukan lagi sebagai satu-satunya sumber pengetahuan yang harus dituruti oleh siswa atau siswa. Guru dapat bertindak sebagai fasilitator dalam mengupayakan kemampuan siswa untuk mengkonstruksi pengetahuan dalam proses kognitifnya. Begitupun dengan peran siswa tidak lagi dipandang sebagai penerima ilmu dari guru, melainkan siswa dipandang sebagai subjek yang memiliki kemampuan untuk secara aktif mencari, mengolah, mengkonstruksi dan menggunakan ilmu pengetahuannya, sehingga pada proses pembelajarannya diberikan kesempatan sebesar-besarnya kepada siswa untuk mengembangkan potensi yang dimiliki agar terjadi peningkatan dan keseimbangan dalam hal kompetensi sikap (attitude), pengetahuan (knowlegde), dan keterampilan (skill).

Salah satu keterampilan yang harus dimiliki siswa, diasah dan diperoleh melalui jalur pendidikan yaitu keterampilan dalam berbahasa. Keterampilan berbahasa merupakan keterampilan yang sangat penting untuk dikuasai mengingat keterampilan seseorang dalam berbahasa kerap dijadikan tolak ukur kecerdasan seseorang. Belajar bahasa pada hakikatnya adalah belajar komunikasi.Dalam Kurikulum 2013, kedudukan bahasa Indonesia bukan hanya sebagai bahasa persatuan tetapi juga sebagai bahasa pengantar dalam proses pembelajaran. Bahasa Indonesia menjadi dasar penting dalam menghela mata pelajaran lainnya (Fakhrur, 2015). Oleh karena itu, keterampilan berbahasa yang dibelajarkan di sekolah diarahkan untuk meningkatkan kemampuan siswa dalam berkomunikasi menggunakan bahasa Indonesia yang baik dan benar. Pembelajaran diarahkan agar siswa menguasai kaidah-kaidah kebahasaan yang merupakan gerbang bagi siswa untuk memasuki dunia ilmu pengetahuan secara lebih mendalam.

Adapun keterampilan berbahasa Indonesia meliputi empat komponen keterampilan, yaitu "keterampilan menyimak, keterampilan berbicara, keterampilan membaca, dan keterampilan menulis" (Tarigan, 2013:1). Keempat keterampilan tersebut pada dasarnya merupakan suatu kesatuan yang diperoleh melalui hubungan yang teratur, dimulai dari masa kanak-kanak seseorang akan belajar menyimak dan berbicara, kemudian seseorang akan belajar membaca dan menulis. Sehingga setiap keterampilan memiliki hubungan yang erat dengan keterampilan yang lain. Untuk mencapai keberhasilan dalam mengembangkan keterampilan berbahasa, maka diperlukan sebuah strategi belajar mengajar yang tepat sesuai dengan tujuan dan karakteristik siswa yang dibelajarkan. Guru dalam hal ini berperan aktif dalam menentukan berbagai macam model pembelajaran yang mampu melibatkan siswa secara aktif mengembangkan keterampilan tersebut. Penggunaan model pembelajaran yang variatif, yang melibatkan keempat komponen keterampilan berbahasa tentunya akan memberikan pengaruh pada penguasaan keterampilan berbahasa Indonesia siswa.

Berdasarkan hasil observasi yang dilakukan pada beberapa SD di Gugus I Kecamatan Gianyar pada tanggal 11 - 13 Januari 2018. Kegiatan pembelajaran yang berlangsung belum optimal dalam mengembangkan keterampilan berbahasa siswa, khususnya pada salah satu komponen keterampilan berbahasa yaitu keterampilan menulis. Sebagian besar siswa merasa bahwa menulis merupakan kegiatan yang sulit dan kurang menyenangkan. Siswa beralasan bahwa kurangnya pemahaman akan materi, terbatasnya ide maupun inspirasi, terbatasnya kosakata yang dimiliki, dan adanya banyak aturan dalam menulis menjadi alasan kegiatan menulis dianggap sebagai hal yang sulit dilakukan. 
Hal ini tidak terlepas dari belum dibiasakannya siswa untuk menggunakan bahasa yang baik dan benar dalam kesehariannya, sehingga menyulitkan siswa dalam menuangkan bahasa yang dimiliki kedalam bentuk tulisan. Keterampilan berbahasa khususnya keterampilan menulis pada dasarnya hanya dapat diperoleh dan dikuasai dengan jalan praktik dan latihan yang banyak. Praktik dan latihan ini dalam jenjang pendidikan formal harus dilaksanakan dalam keadaan nyaman dan menarik untuk menumbuhkan dan mengembangkan keterampilan yang dimiliki siswa.

Salah satu upaya untuk mengoptimalkan kegiatan pembelajaran di kelas agar mampu mengembangkan keterampilan menulis yang dimiliki oleh siswa adalah dengan menerapkan model Reciprocal Teaching. Penerapan model pembelajaran ini "mendorong siswa mengembangkan kemampuan-kemampuan yang dimiliki sebagai pembaca dan pembelajar aktif seperti merangkum, bertanya, mengklarifikasi, memprediksi, dan merespon apa yang dibaca" (Huda, 2016:216). Sehingga berpotensi menumbuhkan semangat belajar siswa yang akan berpengaruh terhadap keterampilan menulis bahasa Indonesia siswa. Menurut Shoimin (2014:153) Reciprocal Teaching merupakan "model yang memberikan kesempatan bagi siswa untuk mempelajari materi terlebih dahulu, kemudian siswa menjelaskan materi yang dipelajari kepada siswa lainnya". Setiap siswa mendapat kesempatan berperan untuk mengajarkan sesama teman (siswa dengan siswa) atau memimpin sebuah diskusi dalam kelompoknya. Dalam penerapannya, guru bertugas sebagai fasilitator dan pembimbing yang mengarahkan atau meluruskan penjelasan mengenai materi yang tidak dapat dipecahkan secara mandiri oleh siswa. Sehingga dalam proses pembelajaran terjadi interaksi timbal balik anatara guru dengan siswa dan siswa dengan siswa. Menurut Shoimin (2014:154) ada beberapa kelebihan model Reciprocal Teaching yaitu. "1) Melatih kemampuan siswa belajar mandiri sehingga kemampuan dalam belajar mandiri dapat ditingkatkan, 2) Melatih siswa untuk menjelaskan kembali materi yang dipelajari kepada pihak lain, 3) Orientasi pembelajaran adalah investigasi dan penemuan yang pada dasarnya adalah pemecahan masalah. Dengan demikian, kemampuan bernalar siswa juga semakin berkembang, 4) Mengembangkan kreativitas dan memupuk kerja sama antar siswa, dan 5) Menumbuhkan sikap menghargai guru karena siswa akan merasakan perasaan menjadi guru pada saat pembelajaran, terutama pada saat siswa ramai atau kurang memperhatikan”.

Dilihat dari penelitian tentang model Reciprocal Teaching yang telah dilaksanakan oleh I Gd Ariyasa pada siswa kelas V SD Negeri 1 Tulamben, dalam penelitiannya diperoleh bahwa model Reciprocal Teaching berpengaruh terhadap hasil belajar IPA setelah diterapkan. Sejalan dengan hal tersebut penelitian yang dilakukan oleh Darmawan pada siswa kelas VIIIB SMP Negeri 16 Singkawang tahun ajaran 2016/2017 menunjukkan bahwa penggunaan model pembelajaran Reciprocal berpengaruh terhadap keterampilan menulis siswa.

Berdasarkan uraian tersebut, maka dilakukan penelitian yang berjudul "Pengaruh Model Reciprocal Teaching Terhadap Keterampilan Menulis Bahasa Indonesia Siswa Kelas V SD Gugus I Kecamatan Gianyar Tahun Ajaran 2017/2018"

\section{Metode}

Penelitian yang dilaksanakan merupakan penelitian kuantitatif dengan jenis penelitian eksperimen semu (quasy experiment). Hal ini dikarenakan eksperimen yang dilakukan tidak memenuhi salah satu kriteria yang dibutuhkan dalam eksperimen sesungguhnya, yaitu randomisasi subjek penelitian. Keterbatasan tersebut yaitu dalam membentuk kelas-kelas yang sesuai dengan rancangan dalam penetapan random, mengingat populasi penelitian telah terdistribusi dalam kelas-kelas yang utuh dan secara administratif sehingga tidak memungkinkan untuk merandom siswa dari sejumlah sekolah untuk dijadikan kelompok eksperimen dan kelompok kontrol.

Eksperimen semu dipilih karena tidak semua variabel dalam penelitian ini dapat dikontrol atau dimanipulasi. Penelitian eksperimen semu merupakan "jenis penelitian yang mempunyai kelompok kontrol akan tetapi tidak dapat berfungsi sepenuhnya dalam mengontrol variabel-variabel luar yang mempengaruhi pelaksanaan eksperimen" (Lestari \& Yudhanegara, 2017:136). Pernyataan ini menunjukkan bahwa hal-hal yang muncul dan mempengaruhi objek penelitian tidak sepenuhnya dapat diawasi. Pengawasan dan pengontrolan hanya dapat dilakukan saat siswa mengikuti proses pembelajaran di sekolah. Adapun rancangan eksperimen semu yang digunakan dalam penelitian ini adalah "Rancangan kelompok Non-ekuivalen"

Populasi yang digunakan dalam penelitian ini adalah seluruh siswa kelas V SD Gugus I Kecamatan Gianyar tahun ajaran 2017/2018 yang terdiri dari 12 kelas dari 7 SD dengan jumlah populasi sebanyak 480 siswa. populasi merujuk pada "keseluruhan kelompok darimana sampel-sampel diambil" (Setyosari, 2016:219).

Adapun sampel dalam penelitian ini ditentukan dengan menggunakan teknik sampel kelompok atau rumpun. Teknik ini digunakan karena populasi penelitian telah terdistribusi ke dalam kelas-kelas yang sudah ada sehingga tidak memungkinkan untuk melakukan pengacakan terhadap individu dari setiap kelas, melainkan yang diacak adalah kelompok kelasnya. Hal ini mengandung arti bahwa seluruh siswa yang berada dalam kelas yang terpilih merupakan sampel penelitian. Teknik sampel kelompok juga dipilih untuk menghindari kemungkinan siswa menyadari dirinya terlibat dalam eksperimen, sehingga penelitian ini mampu menggambarkan keadaan sesungguhnya dengan pengaruh perlakuan yang dieksperimenkan. 
Berdasarkan hasil pengundian dengan teknik sampel kelompok, dari tujuh SD di Gugus I Kecamatan Gianyar, yang menjadi sampel dalam penelitian ini yaitu kelas Va SD Negeri 1 Gianyar dan kelas V SD Negeri 7 Gianyar. "Sampel ialah sebagian dari populasi yang diambil, yang dianggap mewakili seluruh populasi dan diambil dengan menggunakan teknik tertentu" (Agung, 2014:69). Dalam pengertian "sampel adalah sekelompok objek, orang, peristiwa, dan sebagainya yang merupakan representasi dari keseluruhan" (Setyosari, 2016:220). Untuk mendapatkan sampel yang setara maka dilakukan uji kesetaraan berdasarkan nilai tes akhir pembelajaran tema 7 kedua kelompok sampel.

Berdasarkan hasil perhitungan uji kesetaraan diperoleh nilai $t_{\text {hitung }}=1,668<t_{\text {tabel }}=2,000$ yang berarti tidak terdapat perbedaan kedua kelompok sampel atau dapat dinyatakan setara. Kedua kelompok sampel yang telah dinyatakan setara kemudian dirandom kembali untuk menentukan kelompok eksperimen dan kelompok kontrol. Adapun kelompok eksperimen yaitu kelompok yang dibelajarkan dengan model Reciprocal Teaching dalam penelitian ini yaitu siswa kelas V SD 7 Gianyar, dan siswa kelas Va SD 1 Gianyar adalah kelompok kontrol yang dibelajarkan tidak dengan model Reciprocal Teaching.

Dalam penelitian ini diselidiki satu variabel bebas terhadap satu variabel terikat. Variabel terikat dalam penelitian ini yaitu keterampilan menulis bahasa Indonesia siswa, sedangkan variabel bebas dalam penelitian ini yaitu model Reciprocal Teaching.

Data yang diperlukan dalam penelitian ini adalah data tes keterampilan menulis bahasa Indonesia. Untuk mengumpulkan data tersebut, digunakan metode tes yaitu tes keterampilan menulis. Penggunaan tes keterampilan menulis memungkinkan siswa menunjukkan kemampuannya dalam menuangkan hasil pemikirannya ke dalam bentuk bahasa tulis. Tes keterampilan menulis yang digunakan melalui satu penugasan dengan waktu pengerjaan 45 menit. Instrumen tes yang digunakan terlebih dahulu divalidasi dengan cara dikonsultasikan pada jugjes sampai dinyatakan valid. Data dalam penelitian ini diperoleh dengan memberikan pretest dan posttest pada kelompok eksperimen dan kelompok kontrol. Adapun data hasil pretest dan posttest keterampilan menulis bahasa Indonesia dianalisis dengan menggunakan gain skor ternormalisasi.

Metode analisis data yang digunakan dalam penelitian ini adalah metode analisis statistik inferensial. Statistik inferensial digunakan untuk melakukan uji hipotesis. Sebelum uji hipotesis menggunakan analisis statistik uji-t dengan rumus polled varians, dilakukan beberapa uji prasyarat analisis meliputi uji normalitas dengan uji Kolmogororv-smirnov dan uji homogenitas dengan menggunakan uji F.

\section{Hasil dan Pembahasan}

Data yang dianalisis dalam penelitian ini adalah data gain skor ternormalisasi keterampilan menulis bahasa Indonesia siswa kelas V SD Gugus I Kecamatan Gianyar tahun ajaran 2017/2018. Berdasarkan deskripsi data dan analisis data

Berdasarkan deskripsi data dan analisis data keterampilan menulis bahasa pada kelompok eksperimen, diperoleh nilai maksimum sebesar 0,833 dan nilai minimum sebesar 0,100. Rata-rata gain skor ternormalisasi

keterampilan menulis bahasa Indonesia pada kelompok eksperimen yaitu $(\bar{X})=0,433$, varians $\left(\mathrm{s}^{2}\right)=0,025$ dan standar deviasi $(\mathrm{s})=0,158$. Nilai rata-rata dan standar deviasi kelompok eksperimen kemudian dikonversikan pada tabel PAN skala lima sehingga diketahui keterampilan menulis bahasa Indonesia siswa pada kelompok eksperimen berada pada kategori cukup baik.

Pada kelompok kontrol, berdasarkan analisis data yang telah dilakukan diperoleh nilai maksimum sebesar 0,750 dan nilai minimumnya yaitu 0,000. Adapun rata-rata gain skor ternormalisasi keterampilan

menulis bahasa Indonesia kelompok kontrol yaitu $(\bar{X})=0,284$, varians $\left(\mathrm{s}^{2}\right)=0,029$ dan standar deviasi $(\mathrm{s})=$ 0,170. Rata-rata dan standar deviasi tersebut kemudian dikonversikan pada tabel PAN skala lima sehingga diketahui keterampilan menulis bahasa Indoneisa siswa pada kelompok kontrol berada pada kategori cukup baik.

Sebelum melakukan analisis menggunakan uji-t, maka terlebih dahulu dilakukan uji prasyarat analisis meliputi uji normalitas dan uji homogenitas. Uji normalitas sebaran data dimaksudkan untuk meyakinkan bahwa sampel benar-benar berasal dari populasi yang berdistribusi normal, sehingga uji hipotesis dapat dilakukan. Adapun hasil perhitungan dari uji normalitas data kedua kelompok sampel menggunakan uji Kolmogororvsmirnov disajikan pada tabel 1 berikut ini.

Tabel 1. Rekapitulasi Uji Normalitas

\begin{tabular}{ccccc}
\hline No & Kelompok Sampel & $\begin{array}{c}\left|\mathrm{F}_{\mathrm{T}}-\mathrm{F}_{\mathrm{S}}\right| \\
\text { Tertinggi }\end{array}$ & $\begin{array}{c}\text { Nilai Tabel } \\
\text { Kolmogorov- } \\
\text { Smirnov }\end{array}$ & Keterangan \\
\hline 1 & Eksperimen & 0,179 & 0,202 & Berdistribusi Normal \\
\hline 2 & Kontrol & 0,145 & 0,218 & Berdistribusi Normal \\
\hline
\end{tabular}


Kriteria pengujian adalah apabila nilai $\left|\mathrm{F}_{\mathrm{T}}-\mathrm{F}_{\mathrm{S}}\right|$ tertinggi $>$ nilai tabel Kolmogorov-Smirnov, maka data tidak berdistribusi normal. Apabila nilai $\left|\mathrm{F}_{\mathrm{T}}-\mathrm{F}_{\mathrm{S}}\right|$ tertinggi $\leq$ nilai tabel Kolmogorov-Smirnov, maka data berdistribusi normal. Berdasarkan hasil uji normalitas sebaran data kelompok eksperimen diperoleh nilai $\mid \mathrm{F}_{\mathrm{T}}-$ $\mathrm{F}_{\mathrm{S}}$ | tertinggi yaitu 0,179 nilai tersebut digunakan sebagai angka penguji normalitas sebaran data. Adapun jumlah data sebanyak 45 dan pengujian pada taraf signifikansi 5\% maka nilai tabel penguji Kolmogorov-Smirnov yaitu 0,202 sehingga diperoleh perbandingan nilai $\left|\mathrm{F}_{\mathrm{T}}-\mathrm{F}_{\mathrm{S}}\right|$ tertinggi $=0,179<$ nilai tabel Kolmogorov-Smirnov $=$ 0,202 . Berdasarkan hasil tersebut dapat disimpulkan bahwa sebaran data keterampilan menulis bahasa Indonesia siswa pada kelompok eksperimen berdistribusi normal.

Berdasarkan hasil uji normalitas sebaran data kelompok kontrol diperoleh nilai $\left|F_{T}-F_{S}\right|$ tertinggi yaitu 0,145 nilai tersebut akan digunakan sebagai angka penguji normalitas sebaran data. Adapun jumlah data sebanyak 37 dan pengujian pada taraf signifikansi 5\% maka nilai tabel Kolmogorov-Smirnov yaitu 0,218, sehingga diperoleh perbandingan nilai $\left|\mathrm{F}_{\mathrm{T}}-\mathrm{F}_{\mathrm{S}}\right|$ tertinggi $=0,145<$ nilai tabel Kolmogorov-Smirnov $=0,218$. Berdasarkan hasil tersebut maka dapat disimpulkan bahwa sebaran data keterampilan menulis bahasa Indonesia siswa pada kelompok kontrol berdistribusi normal.

Setelah melakukan uji prasyarat pertama yaitu uji normalitas, selanjutnya dilakukan uji homogenitas. Uji homogenitas varians yang dilakukan dalam penelitian ini menggunakan uji F. kriteria pengujian adalah apabila harga $F_{\text {hitung }} \leq F_{\text {tabel}}$, berarti varians homogens. Sedangkan jika $F_{\text {hitung }}>F_{\text {tabel }}$ berarti varians tidak homogen. Pengujian dilakukan pada taraf signifikansi 5\% dengan derajat kebebasan untuk pembilang $\mathrm{n}_{1}-1$ dan derajat kebebasan untuk penyebut $n_{2}-1$. Berikut merupakan rekapitulasi hasil uji homogenitas sampel penelitian yang disajikan pada tabel 2.

Tabel 2. Rekapitulasi Hasil Uji Homogenitas

\begin{tabular}{clccccc}
\hline No & \multicolumn{1}{c}{ Sampel } & $S_{1}^{2}$ & $S_{2}^{2}$ & $\mathrm{~F}_{\text {hitung }}$ & $\mathrm{F}_{\text {tabel }}$ & Keterangan \\
\hline 1 & $\begin{array}{l}\text { Kelompok Eksperimen } \\
2\end{array}$ & 0,029 & & 1,16 & 1,68 & Homogen \\
\hline
\end{tabular}

Berdasarkan hasil analisis diperoleh nilai dari $F_{\text {hitung }}=1,16$. Adapun nilai $F_{\text {tabel }}$ pada taraf signifikansi $5 \%$ dengan $\mathrm{dk}$ pembilang $=36$ dan $\mathrm{dk}$ penyebut $=44$ adalah 1,68 maka diperoleh perbandingan $F_{\text {hitung }}=1,16<F_{\text {tabel }}=1,68$. Sehingga dapat dinyatakan data kedua kelompok memiliki varians yang homogen.

Berdasarkan hasil uji prasyarat yang terdiri dari uji normalitas dan uji homogenitas varians, dapat disimpulkan bahwa data kedua kelompok sampel berdistribusi normal dan memiliki varians yang homogen. Selanjutnya dilakukan pengujian hipotesis, uji hipotesis dilakukan untuk mengetahui pengaruh model Reciprocal Teaching terhadap keterampilan menulis bahasa Indonesia. Pengujian dilakukan terhadapt hipotesis nol $\left(\mathrm{H}_{0}\right)$.

Pengujian hipotesis dalam penelitian ini menggunakan uji-t dengan rumus polled varians dengan kriteria pengujian pada taraf signifikansi 5\% dengan derajat kebebasan $(\mathrm{dk})=\mathrm{n}_{1}+\mathrm{n}_{2}-2$ yaitu jika $\mathrm{t}_{\text {hitung }} \leq \mathrm{t}_{\text {tabel }}$ maka $\mathrm{H}_{0}$ diterima dan $\mathrm{H}_{\mathrm{a}}$ diolak dan jika $\mathrm{t}_{\text {hitung }}>\mathrm{t}_{\text {tabel }}$ maka $\mathrm{H}_{0}$ ditolak dan $\mathrm{H}_{\mathrm{a}}$ diterima. Berikut merupakan rekapitulasi hasil uji hipotesis yang disajikan pada tabel 3 .

Tabel 3. Rekapitulasi Hasil Uji Hipotesis

\begin{tabular}{llccccccc}
\hline No & \multicolumn{1}{c}{ Sampel } & $\mathrm{n}$ & $\mathrm{dk}$ & $\overline{\boldsymbol{X}}$ & $s^{2}$ & $\mathrm{t}_{\text {hitung }}$ & $\mathrm{t}_{\text {tabel }}$ & \multirow{2}{*}{ Keterangan } \\
\hline 1 & Kelompok Eksperimen & 45 & \multirow{2}{*}{80} & 0,433 & 0,025 & \multirow{2}{*}{4,139} & \multirow{2}{*}{2,000} & \multirow{2}{*}{$\mathrm{H}_{0}$ ditolak } \\
2 & Kelompok Kontrol & 37 & & 0,284 & 0,029 & & \\
\hline
\end{tabular}

Berdasarkan hasil perhitungan, diperoleh nilai $t_{\text {hitung }}=4,139$. Adapun nilai $t_{\text {tabel }}$ pada taraf signifikansi $5 \%$ dengan $\mathrm{dk}=\mathrm{n} 1+\mathrm{n} 2-2=45+37-2=80$ menunjukkan nilai $\mathrm{t}_{\text {tabel }}=2,000$. Sehingga diperoleh perbandingan harga $t_{\text {hitung }}=4,139>\mathrm{t}_{\text {tabel }}=2,000$ yang berarti $\mathrm{H}_{0}$ yang menyatakan tidak terdapat perbedaan yang signifikan model Reciprocal Teaching terhadap keterampilan menulis bahasa Indonesia siswa kelas V SD Gugus I Kecamatan Gianyar ditolak. Hal ini berarti terdapat pengaruh model Reciprocal Teaching terhadap keterampilan menulis bahasa Indonesia siswa kelas V SD Gugus I Kecamatan Gianyar tahun ajaran 2017/2018.

Berdasarkan hasil temuan tersebut, kedua kelompok sampel yang telah dinyatakan setara setelah mendapatkan perlakuan berupa pembelajaran dengan menggunakan model Reciprocal Teaching pada kelompok 
eksperimen diperoleh hasil keterampilan menulis bahasa Indonesia yang lebih tinggi. Perolehan hasil analisis data yang telah dilakukan menunjukkan bahwa rata-rata nilai keterampilan menulis bahasa Indonesia siswa pada kelompok eksperimen yaitu 0,433 lebih dari rata-rata nilai keterampilan menulis bahasa Indonesia siswa pada kelompok kontrol yaitu 0.284 dengan selisih nilai sebesar 0,149. Perbedaan hasil keterampilan menuslis tersebut disebabkan oleh perlakuan berupa model Reciprocal Teaching pada kelompok eksperimen. Dengan demikian, model Reciprocal Teaching berpengaruh terhadap keterampilan menulis bahasa Indonesia siswa kelas V SD Gugus I Kecamatan Gianyar tahun ajaran 2017/2018.

Adapun pelaksanaan kegiatan pembelajaran dengan menggunakan model Reciprocal Teaching pada kelompok eksperimen berjalan dengan baik, optimal dan kondusif. Pemberian perlakuan dengan model Reciprocal Teaching menjadikan siswa lebih aktif dalam kegiatan pembelajaran khususnya siswa sebagai pembelajar aktif dengan peran-peran yang ditugaskan pada masing-masing siswa. Siswa dengan bertanggung jawab mampu menjadi seorang pemimpin dalam diskusi kelompoknya, membimbing temannya yang kesulitan dalam memahami materi pelajaran, mampu memecahkan masalah yang ditemui baik secara mandiri maupun berkelompok, dan mampu menyampaikan pendapat baik secara lisan maupun secara tertulis. Siswa juga terlibat aktif untu menyusun pertanyaan dan mengumpulkan informasi berdasarkan teks bacaan yang disediakan. Hal tersebut sejalan dengan pernyataan Huda (2016) yang menyatakan bahwa model Reciprocal Teaching atau timbal balik merupakan salah satu model pembelajaran dengan pendekatan komunikatif yang memungkinkan siswa untuk mampu menggunakan media, menyampaikan dan menerima informasi, belajar dengan orang lain dan membaca serta menulis dengan baik.

Berbeda halnya dengan kelompok kontrol yang melaksanakan pembelajaran tidak menggunakan model Reciprocal Teaching, kegiatan pembelajaran yang berlangsung menyebabkan siswa cepat bosan dan cenderung acuh terhadap pembelajaran dan hanya memperhatikan pekerjaannya sendiri sehingga terlihat kurang antusias dalam kegiatan diskusi kelompoknya. Adanya perbedaan pembelajaran pada kedua kelompok tersebut menunjukkan hasil keterampilan menulis bahasa Indonesia siswa yang berbeda pula.

Berdasarkan landasan teoritik tersebut maka penerapan pembelajaran dengan model Reciprocal Teaching memberikan pengaruh terhadap keterampilan menulis bahasa Indonesia siswa dari pada pembelajaran yang dilaksanakan tidak menggunakan model Reciprocal Teaching.

\section{Simpulan}

Berdasarkan hasil penelitian dan pembahasan maka dapat ditarik simpulan sebagai berikut, terdapat pengaruh model Reciprocal Teaching terhadap keterampilan menulis bahasa Indonesia siswa kelas V SD Gugus I Kecamatan Gianyar tahun ajaran 2017/2018. Hal ini dibuktikan dengan hasil uji-t diperoleh harga $t_{\text {hitung }}=4,139$, sedangkan pada taraf signifikansi $5 \%$ dengan $\mathrm{dk}=80$ menunjukkan nilai $\mathrm{t}_{\text {tabel }}=2,000$. Sehingga dapat diperoleh perbandingan $\mathrm{t}_{\text {hitung }}=4,139>\mathrm{t}_{\text {tabel }}=2,000$ yang berarti hipotesis nol $\left(\mathrm{H}_{0}\right)$ dinyatakan ditolak atau gagal diterima. Hal tersebut menunjukkan bahwa pembelajaran dengan model Reciprocal Teaching berpengaruh terhadap keterampilan menulis bahasa Indonesia siswa kelas V SD Gugus I Kecamatan Gianyar tahun ajaran 2017/2018. Berdasarkan hasil penelitian ini, dapat disampaikan beberapa saran kepada pihak-pihak sebagai berikut.

1. Dengan diadakannya penelitian ini, model Reciprocal Teaching dapat dijadikan sebagai acuan guru dalam pemilihan model pembelajaran yang sesuai dengan kurikulum, muatan pembelajaran dan karakteristik siswa yang dibelajarkan. Kegiatan pembelajaran akan lebih menarik jika dapat divariasikan dengan penerapan model pembelajaran yang ditetapkan dalam Kurikulum 2013. Salah satu model yang direkomendasikan yaitu penerapan pembelajaran dengan model Reciprocal Teaching.

2. Disarankan kepada kepala sekolah agar dapat menciptakan kondisi yang mampu meningkatkan kualitas pembelajaran di sekolah serta mampu mendorong para guru untuk mencoba menerapkan model-model pembelajaran yang sesuai dengan karakteristik siswanya.

3. Kepada para peneliti lain yang berminat untuk mengadakan penelitian lebih lanjut mengenai model Reciprocal Teaching dengan kaitannya terhadap keterampilan menulis bahasa Indonesia siswa maupun bidang ilmu lainnya, agar lebih memperhatikan kendala-kendala yang dialami dalam penelitian ini sebagai bahan pertimbangan dalam melakukan perbaikan dan penyempurnaan penelitian yang hendak dilaksanakan.

\section{Daftar Pustaka}

Agung, A. A. G. 2014. Metodelogi Penelitian Pendidikan. Malang : Aditya Media Publishing.

Ariyasa, I Gd. 2014. Pengaruh Model Pembelajaran Reciprocal Teaching Terhadap Hasil Belajar IPA Siswa Kelas V SD Negeri 1 Tulamben. Jurnal Mimbar PGSD. Universitas Pendidikan Ganesha. (Vol:2, No:1) Tersedia padapasca.undiksha.ac.id. (Diakses tanggal 8 Januari 2018).

Darmadiyasa, Jero Budi. 2016. "Perubahan Kurikulum Dari Masa Ke Masa". Tersedia pada www.jeromath.com.(Diakses pada tanggal 23 Januari 2018). 
Darmawan. 2017. Pengaruh Model Pembelajaran Reciprocal Learning Terhadap Hasil Belajar Keterampilan Menulis pada Siswa Kelas VII B SMP Negeri 16 Singkawang Tahun Ajaran 2016/2017. Jurnal Pendidikan Bahasa dan Sastra Indonesia. STKIP Singkawang. (Vol:2, No:1). Tersedia pada journal.stkipsingkawang.ac.id. (Diakses tanggal 8 Januari 2018)

Fakhrur, M Saifudin. 2015. "Permartabatan Bahasa Indonesia Melalui Pembelajaran Bahasa Indonesia di Sekolah Dasar". Jurnal Pendidikan Guru Sekolah Dasar FKIP UAD. Tersedia pada http://eprints.uad.ac.id/4148/1/M.Fakhrur_PGSD_UAD_Pemartabatan.pdf (diakses tanggal 1 Mei 2018)

Huda, Miftahul. 2015. Model-model Pembelajaran dan Pengajaran. Yogyakarta: Pustaka Belajar.

Lestari, Karunia Eka dan Yudhanegara, M. R. 2017. Penelitian Pendidikan Matematika. Bandung: Refika Aditama.

Setyosari, H.Punaji. 2016. Metode Penelitian Pendidikan dan Pengembangan. Jakarta: PT Kharisma Putra Utama.

Shoimin, Aris. 2014. 68 Model Pembelajaran Inovatif dalam Kurikulum 2013. Yogyakarta: Ar-Ruzz Media.

Tarigan, Henry Guntur. 2013. Menulis Sebagai Suatu Keterampilan Berbahasa. Bandung: CV Angkasa.

Undang-Undang Republik Indonesia no.20 Tahun 2003 tentang Sistem Pendidikan Nasional.2003. Jakarta: Kemendikbud 